\title{
MULTI STAKEHOLDER ENGAGEMENT IN INDONESIA SUSTAINABLE PALM OIL GOVERNANCE
}

\author{
Heldi Yunan Ardian*1, Djuara P. Lubis*), Pudji Muljono*), and Delima Hasri Azahari**) \\ ${ }^{*}$ Human Ecology Faculty, Bogor Agricultural University \\ Kamper Road, IPB Dramaga Campus, Bogor 16680 \\ ${ }^{* *}$ Center for Socio-Economic and Agricultural Policy, Ministry of Agriculture \\ Tentara Pelajar Road No. 3B Bogor 16111
}

\begin{abstract}
Natural resource management generally involves parties with conflicting interests and roles. The emergence of a negative issue on palm oil development in Indonesia heralded by NGOs and vegetable oil competitor countries, for some groups, is considered merely a trade war. The rapid development of Indonesia's oil palm has made this commodity a source of global vegetable oil as well as risen a controversy over its sustainability aspects covering environmental, socio-economic and health issues. The significant increase of palm oil research led to the need to enrich the study's discussion on the sustainability aspect and involved the participation of the related stakeholders. This study is an early stage of a research based on the environmental communication theory to identify the problems and analyze the stakeholders involved in palm oil governance in Indonesia by using stakeholder analysis tools. The methods of data collection in this study included literature review, text analysis, in-depth interviews as well as direct observations. The study finding shows that the Ministry of Agriculture as the main actor in palm oil governance in Indonesia is required to share its authority. This indicates that palm oil sustainability issue is not the responsibility of a particular ministry but has become a national issue that requires the participation and collaboration of all relevant stakeholders.
\end{abstract}

Keywords: palm oil, sustainability, stakeholder analysis

\begin{abstract}
Abstrak: Pengelolaan sumber daya alam umumnya melibatkan pihak-pihak yang memiliki kepentingan dan peran yang saling bertentangan. Munculnya isu negatif tentang pengembangan kelapa sawit di Indonesia yang digembar-gemborkan oleh LSM dan negara pesaing minyak nabati, untuk beberapa kelompok, dianggap hanya sebagai perang dagang. Perkembangan pesat kelapa sawit di Indonesia telah menjadikan komoditi ini sebagai sumber minyak nabati global sekaligus menimbulkan kontroversi mengenai aspek keberlanjutannya yang meliputi masalah lingkungan, sosial ekonomi dan kesehatan. Peningkatan yang signifikan dari penelitian minyak kelapa sawit menyebabkan kebutuhan untuk memperkaya diskusi studi mengenai aspek keberlanjutan dan melibatkan partisipasi pemangku kepentingan terkait. Penelitian ini merupakan tahap awal penelitian berdasarkan teori komunikasi lingkungan untuk mengidentifikasi permasalahan dan menganalisa stakeholder yang terlibat dalam pengelolaan kelapa sawit di Indonesia dengan menggunakan alat analisis pemangku kepentingan. Metode pengumpulan data dalam penelitian ini meliputi: tinjauan pustaka, analisis teks, wawancara mendalam serta pengamatan langsung. Temuan penelitian menunjukkan bahwa Kementerian Pertanian sebagai aktor utama tata kelola minyak sawit di Indonesia diharuskan berbagi kewenangannya. Hal ini menunjukkan bahwa isu keberlanjutan kelapa sawit bukanlah tanggung jawab sebuah kementerian tertentu, namun telah menjadi isu nasional yang mensyaratkan partisipasi dan kolaborasi semua pemangku kepentingan terkait.
\end{abstract}

Kata kunci: kelapa sawit, keberlanjutan, analisis stakeholder

\footnotetext{
${ }^{1}$ Corresponding author:

Email: heldiwow@yahoo.com
} 


\section{INTRODUCTION}

The rapid growth of palm oil in Southeast Asia, especially Indonesia, makes this commodity as a commodity that has an important role in the economic activity in this country. There are at least two issues closely related to this commodity: the competitiveness and sustainability issues. It has been widely discussed that palm oil is one of the few commodities that has high competitiveness in the international market and becomes one of the country's foreign exchange earners. According to the Directorate General of Estate Crops (2015), the export volume of palm oil in 2014 reached 24,372,011 tons with a value of 19 billion US dollars. Oil palm labor intensive also provides benefits to employment. There are 2,052,050 farmers and $3,166,273$ workers who depend on their livelihoods from palm oil. Plantation area increased almost doubled from 6.7 million ha in 2007 to 11.6 million ha in 2016 with total production reaching 6.7 million tons. Smallholder plantations contribute $33.6 \%$ of national palm oil production with plantation area reaching 4.7 million ha or equivalent to $40.8 \%$ of the total area of national palm oil plantation. Related to the issue of competitiveness, Nayantakaningtyas \& Daryanto (2012) stated several threats that need to be seriously reviewed: (i) negative issues (black campaign) of palm oil; (ii) competition with other vegetable oil producing countries; (iii) weak coordination among stakeholders; (iv) political stability, security, and government policy. Improving government policy by taking into account the national and international issues is believed as the essential strategy to solve the problems.

The sustainability aspect is another crucial challenge for the development of this industry. The development of sustainable palm oil according to Yunlong \& Smit (1994) and Rasul \& Thapa (2004), can be viewed from three essential aspects: protecting and improving the natural environment (ecological soundness), maintaining production and productivity (economic viability) as well as social acceptability which refer to independence, equality and improvement of quality of life. However, the growth of the palm oil industry in its development has caused controversy among the international communities, especially in Europe and America which led to trade barriers and declining competitiveness of Indonesian palm oil in the form of negative campaigns. There are at least three major issues related to oil palm development in Indonesia: environmental, socio-economic, and health issues. The most recent negative response to palm oil is the issuance of the European Parliament Resolution on Palm Oil and Deforestation of Rainforests on April 4, 2017. The resolution stated that palm oil products are the cause of deforestation, creating human rights abuses and not supporting sustainability efforts. The negative issues then led to judgment that the controversy of palm oil is actually a matter of "trade war".

The effort to make palm oil more sustainable is in line with the shift of conventional development to more sustainable development. According to Wilkins et al., (2014), sustainable development spawns new indicators and standards requiring complementary certification systems, policy adjustments, more interdisciplinary approaches, and demanding stakeholders in the same ecosystem to learn interpedently in decision making and collective action. The specific characteristics of such sustainable development have implications for the communication process that needs to be applied for palm oil governance improvement. Based on the above introduction, the objective of this study is to identify the related stakeholders and their concern as the initial information for further step of stakeholder analysis.

Environmental communications began to emerge in the early 1960s when Rachel Carson expressed the dangers of pesticides on human health and their impact on the environment, so that environmental communication was always aligned and linked with health communication (Willoughby and Smith, 2016). Burgess \& Harrison (1998) argued that the discourse on the environment between the $80 \mathrm{~s}$ and $90 \mathrm{~s}$, evolving from the previously was not so much discussed into aspects of concern in terms of measurement of its sustainability. This aspect of sustainability is based on the belief that individuals and institutions can be persuaded to accept responsibility for the emergence of environmental problems and change their daily practices to mitigate future environmental impacts.

Environmental communication as the basic theory in this study is defined by Cox (2013) as a study of the ways in which we communicate on the environment, the effects of this communication on our perceptions of both the environment and ourselves, and therefore on our relationship with the natural world. Environmental communication involves not only governance but also the study of public opinion and perception. Lie \& Servaes (2015) classifies environmental communications into a thematic sub-discipline in the field of development 
communication and social changes that address all interactions between humans and the environment.

Of the seven environmental communication study areas proposed by Cox (2013), the study is closely linked to environmental collaboration and conflict resolution. Within this area of study, the problem under study is to find alternative models for addressing dissatisfaction with public participation and conflict resolution methods. An important aspect of this area of study is collaboration by inviting stakeholders to engage in problem-solving discussions and not in the form of advocacy or debate. Collaboration is embodied in a dialogue that focuses on long-term goals, learning processes and power sharing. A successful collaboration begins with seats of stakeholders involved in a table which means that stakeholders are willing to participate in a collective effort to resolve a problem.

\section{METHODS}

This study is an early stage of a research based on the environmental communication theory to identify stakeholders and their concerns in palm oil governance in Indonesia. The methods of data collection in this study included literature review, in-depth interviews, seminars and focus group discussions, observations as well as text analyses generated from news articles, official websites, press releases and other related documents. Stakeholder analysis is used by identifying, categorizing and investigating relationships among stakeholders involved in palm oil governance in Indonesia expected to enable effective collaboration between stakeholders, maintain a balance of forces by preventing the dominance of a particular group and empower farmers as the marginalized groups.

Referring to Reed (2009), a complete stakeholder analysis includes three main stages: identifying stakeholders; differentiating between and categorizing stakeholders; and investigating relationships between stakeholders as presented in Figure 1.

Reed et al. (2009) also emphasizes the important role of stakeholder analysis in natural resource management including: (i) Providing information on who has interests, who has the power to influence, how the parties interact, and based on this information how the possibilities for such stakeholders to collaborate more effectively; (ii) Giving an understanding of the dynamics of power and enhancing transparency and equity in decision making useful for empowering marginalized groups that have no access to social networks, no privileges, socially disadvantaged groups and difficult-to-access groups Geographically; (iii) Preventing the danger of dominance from powerful stakeholders in decision-making and ignoring the voices of marginalized groups; (iv) Understanding the existing collaborative collaborations, potential conflicts and constraints that arise as a result of different interests and providing direction toward relationships among stakeholders.; and (v) Providing recommendations for future activities and stakeholder engagement.

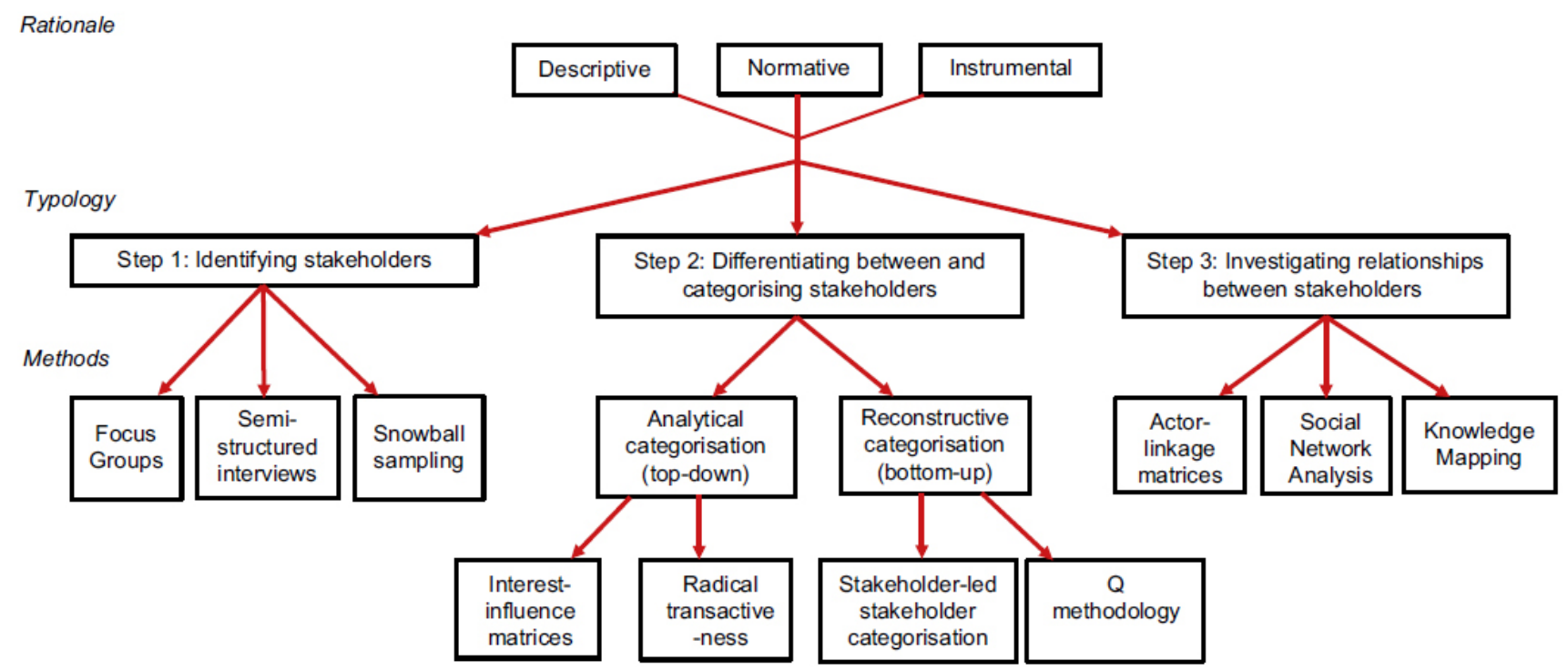

Figure 1. Schematic representation of rationale, typology and methods for stakeholder analysis. 
Furthermore, Grimble and Chan (1995) revealed the reasons why stakeholder analysis is needed: (i) Externalities, i.e. the presence of conditions in a particular area with far-reaching impacts on other areas; (ii) The existence of unclear ownership or ownership rights over natural resources due to the non-functioning of the governing bodies; (iii) The existence of different stakeholders and agenda; and (iv) Exchanges of conditions or trade-offs on policies on the use and management of natural resources such as the occurrence of controversy between national policy objectives encourage forest conservation with the desire of local communities to clear forest land for agriculture.
Text analyses and direct observations were used as the sources of information in identifying stakeholders and their concerns are presented in the following table. The topics and sources of analyzed texts are presented in Table 1. As consideration of the updated data reference, news and documents used in this study were those published in the year of 2017. Direct observations were conducted by attending seminars, focus group discussions and conferences to get a clearer picture of the concerns of each stakeholder as presented in Table 2 .

Table 1. Text Analysis

\begin{tabular}{|c|c|c|}
\hline Text / Document & Date & Source \\
\hline $\begin{array}{l}\text { Regulation of the Minister of Environment and } \\
\text { Forestry on peat ecosystem is considered potentially } \\
\text { disturbing economic independence. }\end{array}$ & 8 August 2017 & $\begin{array}{l}\text { https://ekbis.sindonews.com/read/1228053/34/ } \\
\text { permen-ekosistem-disebut-akan-ganggu- } \\
\text { kemandirian-ekonomi-1502113028 }\end{array}$ \\
\hline $\begin{array}{l}\text { Hearings Transcript of Commission IV Indonesia } \\
\text { House of Representatives about European Parliament } \\
\text { Resolution Related To Oil Palm }\end{array}$ & 18 April 2017 & $\begin{array}{l}\text { Bureau of Public Relations and Information, } \\
\text { Ministry of Agriculture }\end{array}$ \\
\hline KPK Assessment on Palm Oil Fun Disbursement & 25 April 2017 & $\begin{array}{l}\text { http://katadata.co.id/berita/2017/04/25/kpk- } \\
\text { penyaluran-dana-pungutan-sawit-salah-sasaran }\end{array}$ \\
\hline $\begin{array}{l}\text { Ministry of Industry and Discuss Ministry of } \\
\text { Environment and Forestry Discussion on Peat } \\
\text { Regulation }\end{array}$ & 19 May 2017 & $\begin{array}{l}\text { http://ekonomi.kompas.com/ } \\
\text { read/2017/05/19/105431426/kemenperin. } \\
\text { diskusikan.pp.gambut.dengan.kementerian.lhk }\end{array}$ \\
\hline $\begin{array}{l}\text { Palm Oil Companies Ask for Support to Reject EU } \\
\text { Resolution }\end{array}$ & 23 April 2017 & $\begin{array}{l}\text { http://www.republika.co.id/berita/ekonomi/ } \\
\text { makro/17/04/23/oout1d382-pengusaha-sawit- } \\
\text { minta-dukungan-tolak-resolusi-uni-eropa }\end{array}$ \\
\hline Greenpeace's letter to President Joko Widodo & 22 June 2017 & $\begin{array}{l}\text { http://www.greenpeace.org/seasia/id/press/ } \\
\text { releases/Surat-Greenpeace-untuk-Presiden- } \\
\text { Joko-Widodo/ }\end{array}$ \\
\hline $\begin{array}{l}\text { WWF-Indonesia Statement of Aidenvironment } \\
\text { Consultant's Publication: Investments from Nordic } \\
\text { Countries in Several Banks in Indonesia Providing } \\
\text { Financing of Palm Oil Sector }\end{array}$ & 31 May 2017 & $\begin{array}{l}\text { http://www.wwf.or.id/?57662/Pernyataan- } \\
\text { WWF-Indonesia-terhadap--Publikasi-Laporan- } \\
\text { Konsultan-Aidenvironment---Investasi- } \\
\text { dari-Negara-negara-Nordik-pada-Beberapa- } \\
\text { Bank-di-Indonesia-yang-Memberikan- } \\
\text { PembiayaanSektor-Kelapa-Sawit }\end{array}$ \\
\hline $\begin{array}{l}\text { Visit Russia, Minister Enggar Bring the Mission of Oil } \\
\text { Palm Diplomacy }\end{array}$ & 3 August 2017 & $\begin{array}{l}\text { https://bisnis.tempo.co/read/ } \\
\text { news/2017/08/03/090896812/kunjungi-rusia- } \\
\text { menteri-enggar-bawa-misi-diplomasi-minyak- } \\
\text { sawit }\end{array}$ \\
\hline $\begin{array}{l}\text { Minister of Trade Ensures that Indonesia's Oil Palm is } \\
\text { the Best in the World }\end{array}$ & 3 August 2017 & $\begin{array}{l}\text { http://www.tagar.id/menteri-perdagangan- } \\
\text { jamin-sawit-indonesia-terbaik-di-dunia/ }\end{array}$ \\
\hline $\begin{array}{l}\text { Response to European Parliament Resolution on Palm } \\
\text { Oil }\end{array}$ & 8 April 2017 & $\begin{array}{l}\text { http://www.kemlu.go.id/id/berita/Pages/ } \\
\text { Tanggapan-Atas-Resolusi-Parlemen-Eropa- } \\
\text { Tentang-Minyak-Sawit-.aspx }\end{array}$ \\
\hline Palm Oil Diplomacy & 8 July 2017 & $\begin{array}{l}\text { https://kompas.id/baca/opini/2017/07/08/ } \\
\text { diplomasi-ekonomi-sawit/ }\end{array}$ \\
\hline
\end{tabular}


Table 2. Direct observation

\begin{tabular}{|c|c|c|}
\hline Direct Observation & Date & Initiator \\
\hline $\begin{array}{l}\text { Book Launch: } 6 \text { Years of ISPO Implementation } \\
\text { (Indonesia Sustainable Palm Oil) }\end{array}$ & 30 March 2017 & Forest Watch \\
\hline $\begin{array}{l}\text { The Logic on Expansion of Oil Palm Plantation } \\
\text { Versus Deforestation }\end{array}$ & 6 April 2017 & $\begin{array}{l}\text { Thamrin School of Climate Change and } \\
\text { Sustainability }\end{array}$ \\
\hline $\begin{array}{l}\text { International Conference on Indonesian } \\
\text { Sustainable Palm Oil (IC-ISPO) } 2017\end{array}$ & 11 April 2017 & $\begin{array}{l}\text { Media Perkebunan, Ministry of Agriculture and } \\
\text { Ministry of Environment and Forestry }\end{array}$ \\
\hline $\begin{array}{l}\text { Panel discussion and press conference "Kartini } \\
\text { and gender equality in Indonesian palm } \\
\text { oil (Acceleration of Sustainable Palm Oil } \\
\text { Application: Challenges and Opportunities in } \\
\text { Indonesia)" }\end{array}$ & 20 April 2017 & $\begin{array}{l}\text { IDH -the Sustainable Trade Initiative and Thamrin } \\
\text { School of Climate Change and Sustainabilit }\end{array}$ \\
\hline National Conference of Indonesian Plantation & $\begin{array}{l}\text { 26-27 April } \\
2017\end{array}$ & $\begin{array}{l}\text { Indonesia Farmers Union (SPI), Oil Palm Farmers } \\
\text { Union (SPKS, Indonesian Farmers Alliance (API), } \\
\text { Sawit Watch, Farmer Initiative for Ecological } \\
\text { Livelihood and Democratie (FIELD), Bina Desa dan } \\
\text { (Indonesian Human Rights Committee for Social } \\
\text { Justice) IHCS. }\end{array}$ \\
\hline The 1st National Communication Forum & 21 July 2017 & $\begin{array}{l}\text { Lingkar Temu Kabupaten Lestari (LTKL) and } \\
\text { Association of Local Government of Indonesia } \\
\text { (APKASI) }\end{array}$ \\
\hline
\end{tabular}

\section{RESULT}

As an initial stage of the analysis, stakeholder identification in sustainable palm oil governance was identified and divided into three main groups: The government consisting of the relevant Ministries, Indonesian Oil Palm Estate Fund Agency/BPDPKS), Corruption Eradication Commission (KPK) and the House of Representatives (Commission IV); Non-governmental organizations that include: environmentalist organizations and farmers association; academics and research institutions. The complete list of the identified stakeholders is presented in Table 3.

Information obtained from text analyses and direct observations was examined and tabulated to determine the concerns of each stakeholder. The concerns from each stakeholder group were identified and grouped based on their similar issues. The result of this identification indicates that there are 15 major issues as appear in Figure 2. The figure below shows the average value of each stakeholder group's concern.

The government group focused more on the contribution of oil palm to the economic aspects and pro-farmer policy ( 7 and 6 point respectively). This is in line with the current national government agenda based on NAWACITA which puts economic independence and people welfare as the top priority. On the other hand, the NGO stakeholder group, in accordance with their vision, mission and function in monitoring of palm oil governance, certainly gave their main supports on the environmental sustainability issue ( 9 points). The NGO group was also the only group that voiced a moratorium on expansion of palm oil plantations and human rights issues ( 3 points and 1 point respectively).

Furthermore, the academic and research center stakeholder group was more concerned about the negative issues that discredited Indonesian oil palm similar to the government stakeholder group (4 points). Mudde et al. (2016) revealed several roles and tasks of academic and research center including: (i) independent facilitator-initiator; (ii) improvement of the quality of student work; (iii) encouragement on the research based process and (iv) focus and openness for partnering with a diversity of stakeholders, like business development support organizations and financiers.

Last but not least, business stakeholder group paid their attention at two main concerns, namely, economic and negative campaigns. Instead of discussing and responding further on the palm oil negative issues, Chalil (2015) suggested the government to be more focused on the improvement of efficiencies and provide competitive selling prices to meet demands from India and China the two biggest importers countries. RSPO 
as a certification system that refers to the acceptability of Indonesian palm oil in the European countries should be proportionally reviewed since it requires a considerable amount of money with a large amount of effort, but the uptake and premium prices are still low.

The issue of the possibility of adoption of INDO TLAS/SVLK as a reference for certification of oil palm sustainability appears in the process of strengthening
ISPO certification which is still debatable. INDO TLAS/ SVLK is a multi-stakeholder tracking system to ensure the legality of sources of timber in order to enhance the acceptability of this commodity in the European market. However, the Ministry of Agriculture has a pessimistic view on it and assumes that SVLK cannot be used as a reference for ISPO strengthening due to their principle differences.

Table 3. The identified stakeholder

\begin{tabular}{ll}
\hline Government & Non-governmental and Other Organization \\
\hline Coordinating Ministry of Economic Affairs & Sawit Watch \\
Ministry of Agriculture & Oil Palm Farmers Union (SPKS) \\
Ministry of Agrarian Affairs and Spatial Planning & Indonesia Biodiversity Foundation (Yayasan KEHATI) \\
Ministry of Environment and Forestry & Rainforest Alliance \\
Ministry of Foreign Affairs & United Nations Development Programme (UNDP) \\
Ministry of Trade Ministry of Industry & Forest Watch Indonesia \\
Indonesian House of Representatives (Commission IV) & Indonesian Forum for the Environment (WALHI) \\
Indonesian Oil Palm Estate Fund Agency (BPDPKS & Roundtable on Sustainable Palm Oil (RSPO) \\
Corruption Eradication Commission (KPK) & Greenpeace Indonesia \\
& World Wildlife Fund (WWF) \\
& Indonesian Oil Palm Farmers Association (APKASINDO) \\
\hline University and Research Center & IDH-The Sustainable Trade Initiative \\
\hline Bogor Agricultural University (IPB) & Business \\
Lampung University & Golden-Agri Resources (GAR) \\
Center for International Forestry Research (CIFOR) & Indonesian Palm Oil Association (GAPKI) \\
Research Center for Climate Change (RSCC), University of & \\
Indonesia & \\
\hline
\end{tabular}

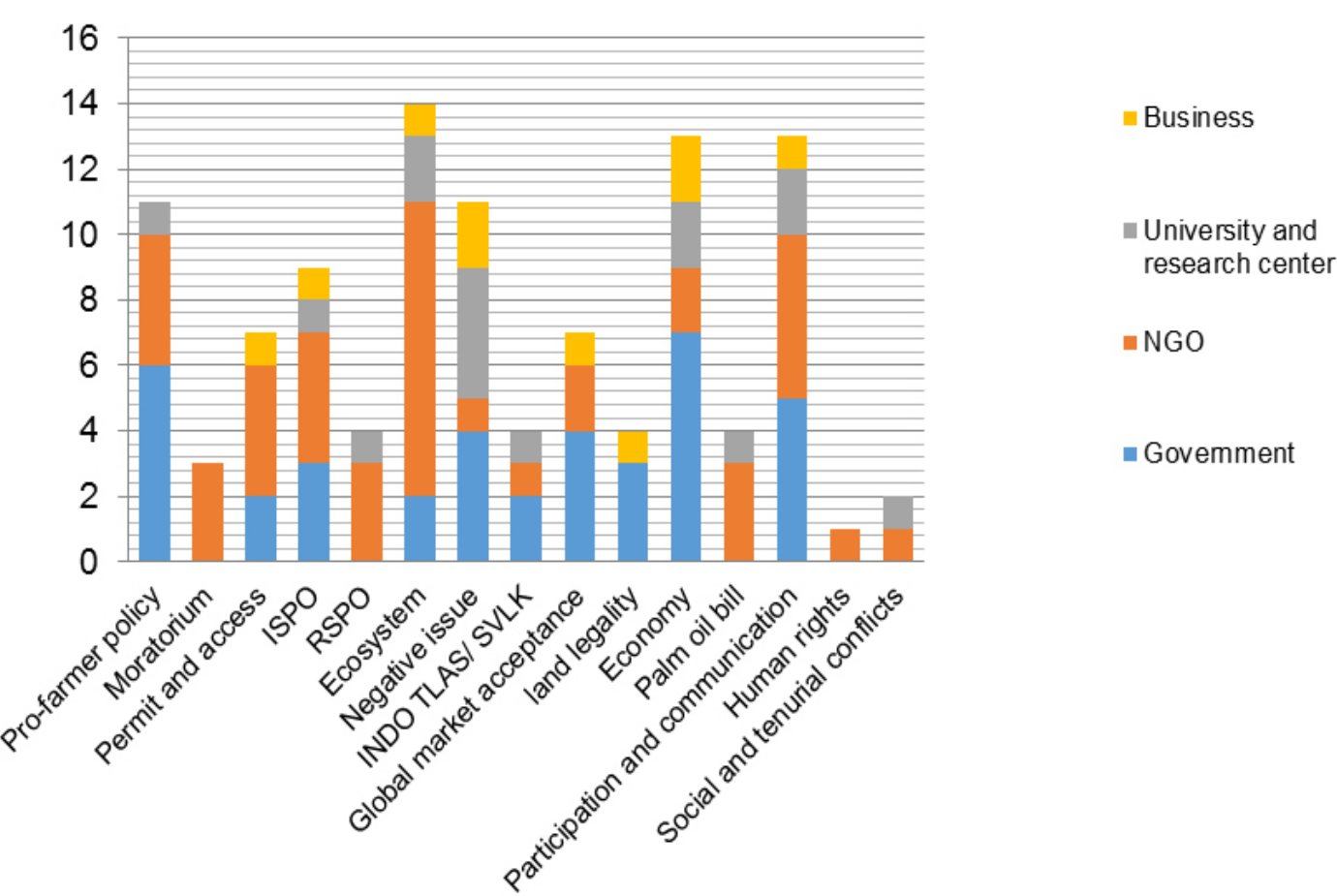

Figure 2. Stakeholder identification and their main concern 
Other interesting finding indicates that the issue of participationandcommunicationfrommultistakeholders becomes the main concern of both the government and NGOs. The issue leads to the need for multi-stakeholder involvement, particularly NGOs, in the process of ISPO strengthening formulation that has been considered by some parties as the full authority of the government. Iqbal (2007) and Reed (2008) argued that stakeholder participation is essential for sustainable development and should be institutionalized in the form of forums for the identification of perceptions, commitments, collective decisions, and activity synergies to support the smoothness of agricultural development programs. Harsono et al. (2012) underlined that although ISPO is a government program, support from all palm oil stakeholders, is strongly needed.

Figure 3 above provides an overview of the proportion of stakeholder concerns ranging from the most concern to the least. The presented figures are the sum of the common concerns belong to 28 stakeholders that had been identified. In principle, all stakeholders agreed that the issue that must be addressed immediately in palm oil governance is the environmental problem covering the issue of deforestation and forest fires (14 points). In the second position, there were two important issues that become concerned: the economic aspects that include sources of foreign exchange income, business sustainability and investment as well as the communication problems among stakeholders that indicate the demands for the government to involve public participation in palm oil governance. Specifically, Cox (2010) outlines the requirements that must be met to create the success of collaboration among stakeholders, namely, the agreement of the stakeholders in sitting at one table and participating in a joint effort in solving the problem to obtain a consensus.

Over the past few years, the contestation between ISPO and RSPO has emerged as a result of the hegemony of export-oriented palm oil development, particularly by the consumers in Europe, who then shifted back from the private sector to the government after the emergence of ISPO in 2011 (Pichler, 2013 and Sahide et al. 2013). As presented in Table 3 above, it appears that ISPO and RSPO are no longer subject to debate. This can be a successful example of the role of communication among stakeholders. The joint study of the similarities and differences between ISPO and RSPO certification facilitated by UNDP ends in a consensus to harness as much similarities of the two certification systems as possible as a basis for conducting certification joint audit more efficiently. On the other hand, the issue of ISPO will continue to be the concern of many parties as a consequence of the ISPO reinforcement process that was previously regulated by the Minister of Agriculture regulation into Presidential Regulation.

Figure 4 shows the existence of the non-government elements and other related institutions in the process of ISPO reinforcement that indicates there is a demand to establish a transparent and credible palm oil governance. Ministry of Agriculture, which was previously the sole main actor, needs to open access for public participation and be willing to sit together with other related stakeholders, especially related to the supervisory function which presumably still needs a lot of improvement.

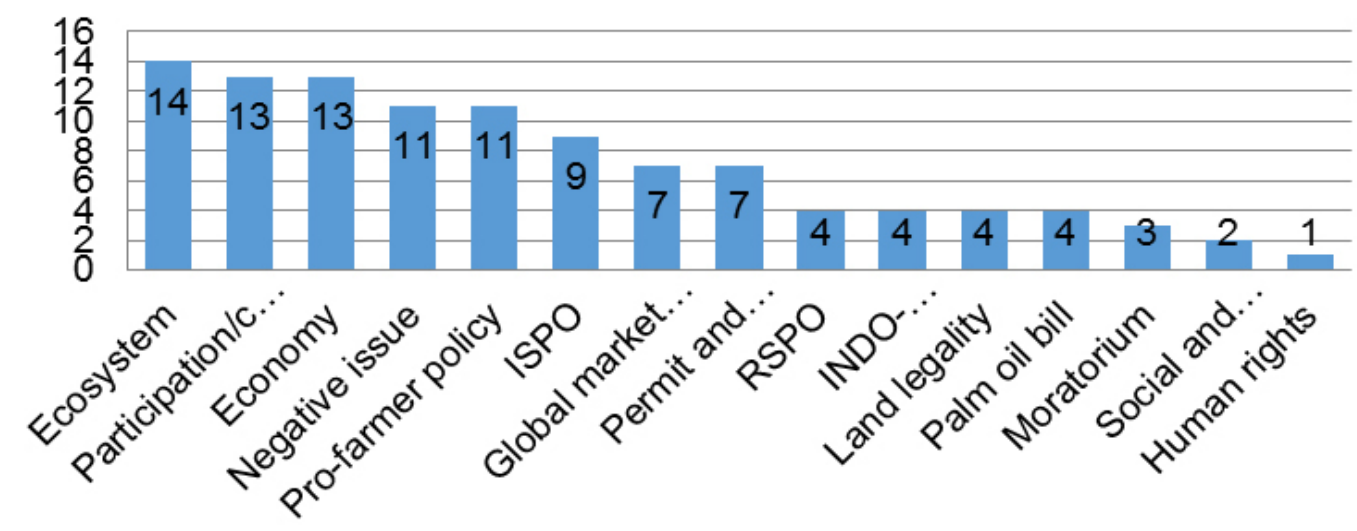

Figure 3. The proportion of stakeholders' concern 


\begin{tabular}{|c|c|c|}
\hline & & \multirow{2}{*}{$\begin{array}{l}\qquad \begin{array}{l}\text { ISPO Strengthening Team } \\
\text { Working Team }\end{array} \\
\text { Chairman: Assistant Deputy for Plantation } \\
\text { and Horticulture, Coordinating Ministry for } \\
\text { Economic Affairs } \\
\text { Vice chairman: Senior Advisor of Indonesia } \\
\text { Biodiversity Foundation (Yayasan KEHATI) }\end{array}$} \\
\hline $\begin{array}{l}\text { ISPO Commission } \\
\text { Chairman: DG of Estate Crops, MOA } \\
\text { Vice chairman: DG of Agricultural } \\
\text { Marketing and Processing Product, } \\
\text { MOA }\end{array}$ & $\begin{array}{l}\text { ISPO Strengthening Team } \\
\text { Steering Committee } \\
\text { Chairman: Deputy for Food and } \\
\text { Agriculture Coordination, Coordinating } \\
\text { Ministry for Economic Affairs }\end{array}$ & \\
\hline \multirow[t]{3}{*}{$\begin{array}{l}\text { - Coordinating Ministry for Economic } \\
\text { Affairs } \\
\text { - Ministry of Trade } \\
\text { - Ministry of Environment and Forestry } \\
\text { - National Land Agency } \\
\text { - National Standardization Agency } \\
\text { - Association of Indonesian Palm Oil } \\
\text { Producer (GAPKI) } \\
\text { - Indonesian Palm Oil Board (DMSI) }\end{array}$} & $\begin{array}{l}\text { - Coordinating Ministry for Economic } \\
\text { - Mffairs } \\
\text { - Ministry of Trade } \\
\text { - Natistry of Environment Land Agency } \\
\text { - National Standardization Agency } \\
\text { - Association of Indonesian Palm Oil } \\
\text { - Producer (GAPKI) } \\
\text { - Indonesian Palm Oil Board (DMSI) }\end{array}$ & $\begin{array}{l}\text { - Coordinating Ministry for Economic } \\
\text { - Mffairs } \\
\text { - Ministry of Trade } \\
\text { - Matistry of Environment and Forestry } \\
\text { - National Standardization Agency } \\
\text { - Association of Indonesian Palm Oil } \\
\text { - Producer (GAPKI) } \\
\text { - Indonesian Palm Oil Board (DMSI) }\end{array}$ \\
\hline & $\begin{array}{l}\text { - Ministry of Agriculture } \\
\text { - Ministry of Industry; } \\
\text { - Indonesian Oil Palm Estate Fund Agency } \\
\text { (BPDPKS) }\end{array}$ & $\begin{array}{l}\text { - Ministry of Agriculture } \\
\text { - Ministry of Industry; } \\
\text { - Indonesian Oil Palm Estate Fund Agency } \\
\text { (BPDPKS) }\end{array}$ \\
\hline & $\begin{array}{l}\text { - Ministry of Foreign Affairs; } \\
\text { - Indonesia Biodiversity Foundation } \\
\text { (Yayasan KEHATI) } \\
\text { - Strategic Plantation Development Forum }\end{array}$ & $\begin{array}{l}\text { - National Standardization Agency (BSN) } \\
\text { - National Accreditation Committee (KAN) } \\
\text { - Secretariat of the Indonesian Sustainable } \\
\text { - ISPO Secretariat } \\
\text { - Association of Indonesian Certification } \\
\text { Institutions (ALSI) }\end{array}$ \\
\hline
\end{tabular}

Figure 4. The Stakeholder involved in the strengthening of ISPO

The elevation of authority to improve the governance of oil palm from the Ministry of Agriculture to the Coordinating Ministry for Economic Affairs is a significant step forward considering the slow progress of ISPO certification. This strategic approach may move the Indonesian's government to enhance its capacity for improving policy and implementation over time by also considering the many interests involved in palm oil governance. Related to this issue, Harsono et al. (2012) argued that ISPO should not only be owned by the Agriculture Ministry, rather it should be elevated to a higher level. By elevating ISPO to a higher authority, ISPO will obtain more attention and support; also, ISPO will provide stronger impact, enforcement and faster accomplishment.

\section{Managerial Implications}

The elevation of the authority to improve the governance of oil palm from the Ministry of Agriculture to the Coordinating Ministry for Economic Affairs is a significant step forward considering the slow progress of ISPO certification. This strategic approach may move the Indonesian government to enhance its capacity for improving policy and implementation over time by also considering the many interests involved in palm oil governance.

Responding to the negative issues associated with oil palm, the Indonesian government should not necessarily take a defensive stance and argue that the issue is completely untrue. Indonesia should wisely confess that palm oil governance in Indonesia still needs a lot of improvement. In addition, diplomatic efforts supported by the transparency of information and the availability of scientific evidence as well as the open communication among stakeholders need to be continued for the development of sustainable palm oil.

\section{CONCLUSIONS AND RECOMMENDATIONS}

\section{Conclusions}

The study finding shows that the multi-stakeholder approach is required to improve sustainable palm oil governance in Indonesia. Ministry of Agriculture as the main actor in palm oil governance in Indonesia 
is required to share its authority which indicates that palm oil sustainability issue is not the responsibility of a particular ministry, but has become a national issue that requires the participation and collaboration of all relevant stakeholders.

Debates and controversy over Indonesian palm oil governance should culminate in the balance of each component of sustainability. All engaged stakeholders need to recognize that the opening of sphere for participation is not to win the pro-environmental group or defend the pro-economic party or even undermine the government's position as the regulator. The conflict of interest that occurs to maintain a balance among the environmental, economic and social aspects in palm oil governance requires each party, either as an individual or as a representation of a particular stakeholder, to make some changes in order to obtain their expected goal.

\section{Recommendations}

Future research can focus on disclosing what factors affect the performance of each hedge ratio, such as commodity futures market liquidity, and macroeconomic conditions. The hedge ratio estimation method can be further developed to capture more sharp asymmetric volatility and co-integration tests using a more robust test method.

\section{REFERENCES}

Burgess J, Harrison CM. 1998. Environmental communication and the cultural politics of environmental citizenship. Environment and Planning A: Economy and Space 30(8): 14451460. https://doi.org/10.1068/a301445.

Chalil D. 2016. Sustainability of sustainable palm oil: a market integration analysis. Jurnal Manajemen \& Agribisnis 13(2): 157-167. https://doi. org/10.17358/JMA.13.2.157.

Cox R. 2013. Environtemental Communication and the Public Sphere. 3rd Edition. Los Angeles: Sage.

Directorate General of Estate Crops (Direktorat Jenderal Perkebunan). 2015. Statistik Perkebunan Indonesia 2014-2016 Kelapa Sawit. Jakarta: Kementerian Pertanian.

Grimble R, Chan MK. 1995. Stakeholder analysis for natural resource management in developing countries: some practical guidelines for making management more participatory and effective. Natural Resources Forum 19: 113-124. https:// doi.org/10.1111/j.1477-8947.1995.tb00599.x.

Harsono D, Chozin MA, Fauzi AM. 2012. Analysis on Indonesian sustainable palm oil (ISPO): a qualitative assessment on the success factors for ISPO. Jurnal Manajemen \& Agribisnis 9 (Special Edition): 39-48.

Iqbal M. 2007. Analisis peran pemangku kepentingan dan implementasinya dalam pembangunan pertanian. Jurnal Litbang Pertanian 26(3): 8999.

Lie R, Servaes J. 2015. Disciplines in the Field of Communication for Development and Social Change. Communication Theory 25: 244-258. https://doi.org/10.1111/comt.12065.

Mudde H, Indrawan RD, Fahmi I. 2012. Multisector partnerships for sustainable business development: lessons learned from Round Table Indonesia. Jurnal Manajemen \& Agribisnis 9 (special edition): 7-18. Doi: http://dx.doi. org/10.17358/jma.9.2.7-18.

Nayantakaningtyas JS, Daryanto HK. 2012. Daya saing dan strategi pengembangan minyak sawit di Indonesia. Jurnal Manajemen \& Agribisnis 9 (3): 194-201. Doi: http://dx.doi.org/10.17358/ jma.9.3.194-201.

Pichler M. 2013. "People, planet \& profit": consumeroriented hegemony and power relations in palm oil and agrofuel certification. Journal of Environment \& Development 22(4): 370-390. https://doi.org/10.1177/1070496513502967.

Rasul G, Thapa G. 2004. Sustainability of ecological and conventional agricultural systems in Bangladesh: an assessment based on environmental, economic and social perspectives. Agricultural Systems 79: 327-351. https://doi.org/10.1016/j. biocon.2008.07.014.

Reed MS. 2008. Stakeholder participation for environmental management: a literature review. Biological Conservation 141: 2417-2431. doi:10.1016/j.biocon.2008.07.014.

Reed MS, Graves A, Dandy N, Posthumus H, Hubacek K, Morris J, Prell C, Quinn CH, Stringer LC. 2009. Who's in and why? A typology of stakeholder analysis methods for natural resources management. Journal of Environmental Management 90: 1933-1949. https://doi.org/10.1016/j.jenvman.2009.01.001.

Sahide MAK, Burns S, Wibowo A, Nurrochmat DR and Giessen L. 2015. Towards state hegemony 
over agricultural certification: from voluntary private to mandatory state regimes on palm oil in Indonesia. Jurnal Manajemen Hutan Tropika 21(3):162-171.http://journal.ipb.ac.id/index. php/jmht/article/view/10798.

Wilkins KG, Tufte T, Obregon R. 2014. The Handbook of Development Communication and Social Change. West Sussex: John Wiley \& Sons Ltd. https://doi.org/10.1002/9781118505328.
Willoughby JF, Smith H. 2016. Communication strategies and new media platforms: exploring the synergistic potential of health and environmental communication. Science Communication 38(4): 535-545. https://doi. org/10.1177/1075547016648151.

Yunlong C, Smith B, 1994. Sustainability in agriculture: a general review. Agriculture. Ecosystems and Environment 49: 299-307. https://doi. org/10.1016/0167-8809(94)90059-0. 